\title{
10分雨量データを用いた 愛知県における短時間強雨の雨量解析 PRECIPITATION ANALYSIS OF HEAVY RAINFALLS IN AICHI PREFECTURE USING 10-MINUTE PRECIPITATION DATA
}

\author{
庄 建治朗 1 ・谷口 健司 ${ }^{2} \cdot$ 冨永 晃宏 $^{3}$ \\ Kenjiro SHO, Kenji TANIGUCHI and Akihiro TOMINAGA \\ 1正会員 博 (工) 名古屋工業大学助教 ながれ領域 ( 4 466-8555 名古屋市昭和区御器所町) \\ 2 正会員 博 (工) 金沢大学特任助教 理工研究域環境デザイン学系 († 920-1192 金沢市角間町) \\ 3正会員 工博 名古屋工業大学教授 ながれ領域 (
}

\begin{abstract}
Precipitation analysis for heavy rainfalls in Tokai district on September 11-12, 2000 and August 28-29, 2008 was performed based on 10-minute precipitation data. Rainfall distribution analyses showed that a rain band in the direction of the prevailing wind at middle levels slowly moved eastward on the western Aichi Prefecture throughout the both events. The rain band consisted of aligned heavy-rain cells of about 5-10 km diameter that traveled successively along the rain band. The band lay 10-20 km toward the cold sector of a meso-scale convergence line. Moreover, an analysis of 10-minute precipitation data for the past 22 years revealed that the areas including the northern Chita Peninsula and Nagoya City have a maximum frequency of heavy rain of short duration despite having the lowest annual total precipitation in Aichi Prefecture. Thus, these areas seem to have topographic characters favoring concentrated heavy rainfall only under specific meteorological conditions.
\end{abstract}

Key Words : 10-minute precipitation data, localized heavy rainfall, meso-scale convergence line, Nagoya, Aichi Prefecture

1 . はじめに

東海地域では、局地的に集中した豪雨による浸水被害 が近年度々発生している。特に、名古屋市を含む愛知県 西部では、人口や資産が低地の平野部に集積しているた め、光の対策か切実に求められる。しかし、空間的・時 間的に限られた範囲に集中した強雨は、光の地域のメソ 気象か関係するため、発生位置や時刻、規模等を正確に 予測することは現段階では難しい。

2010 年度より、国土交通省によるXバンドMPレー ダーの試験運用か東海地域においても開始され、今後の 局地的豪雨の監視に威力を発揮することか期待されてい る。レーダーデータは、降雨システムの構造等を調べる には有効な手段であるが、技術進歩に伴ってデータの仕 樣等力瀕繁に変化しているため、ある程度以上の長期に わたって過去の豪雨の降雨特性を同じ条件で比較するの には必ずしも適していない。また、レーダーデータは降 雨量光のものを観測したものではないため、雨量予測や 洪水対策への展開を視野に入れた場合には、地上雨量
データを用いて過去の豪雨について雨域特性等を詳細に 解析しておくことも意義あることと思われる。

名古屋市や愛知県では、市内・県内に多数の雨量計を 配置しており、10分間雨量の観測データが10数〜20年分 程度蓄積されている。著者らは、東海地域、とりわけ名 古屋を中心とする愛知県における局地的な強雨の予測精 度向上を目的として、物理モデルによるアプローチと併 せ、過去の観測データに基づく経験的・統計的な予測手 法について研究を行っている。关うした観点から本稿で

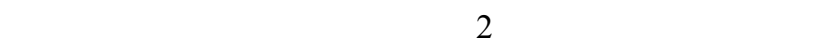
について、詳細な雨量分布、雨域の移動特性や周辺の気 象状況との関連を地上雨量データに基づいて解析する。 また、過去の10分雨量データを用いて、愛知県における 短時間強雨の発生頻度の特性についても検討し、強雨の 発生しやすい地域や発生時の気象条件等の抽出を目指す。

\subsection{0 分雨量データを用いた豪雨事例の解析}

本稿の解析で主として使用したデータは、愛知県建設 
部河川課所管の58地点の観測局（当初46地点から徐々に 増加）における1987〜2008年の10分間降水量データと、 名古屋市所管の32地点の観測局 (2001年以前は30地点) における1999〜2009年の10分間降水量データである。特 に雨量計か滵に配置されている名古屋市域を中心に検討 を行った。

まず、名古屋市域における近年の短時間強雨の事例を 抽出するため、1999〜2009年の資料期間において名古屋 市所管観測局の何れかで60分間雨量 (生起時刻の前60分 間雨量) が $50 \mathrm{~mm}$ 以上となった日数を求めたところ、27 日であった（日界を挟んて明らかにひと続きの降雨と見 なせる場合は2日にわたっていても1日と数えた）。これ らは全て6〜9月の夏季に発生しており、うち13例は8月、

7例は9月であった。また、最大 60 分雨量の生起時刻を時 間帯別に見ると、27例中 11 例が18:00〜24:00、8例が 12:00〜 18:00、7例が:00〜 6:00、1例が6:00〜12:00であり、 夕方から夜間の発生が多いのか特徽的である。最大 60 分 雨量の上位10例の強雨を表-1に示す。

以下では、特に大きい雨量を記録した 2000 年9月 11 日 (東海豪雨) と2008年8月29日 (平成20年8月末豪雨) の 事例について、雨域や関連する気象状況について検討す る。

\section{(1) 2000 年9月東海豪雨}

a) 概況

2000 年9月 11 日から 12 日朝にかけ、愛知県西部を中心 に東海地方は激しい雷を伴う大雨に見舞われた。名古屋 地方気象台では、2日間総雨量567mm（11〜12日）、最 大時間雨量 $93 \mathrm{~mm}$ (11日18 19時) と何れも観測史上最 大を記録、周辺でも多くの地点て記録的大雨か観測され た。この大雨により、鉄道、道路の交通網は寸断され、 名古屋市西区て新川左岸堤防が決壊するなど都市域で中 小河川の破堤、溢水、内水氾濫か相次ぎ、また岐阜県南 東部から愛知県北部にかけての矢作川上流域等でも河川 の氾濫、土砂災害が各所で発生、愛知県内で死者7名、 床上・床下浸水計 65000 棟以上を数える大災害となった。 豪雨当日、日本列島上空には秋雨前線が停滞し、これ

表-1 名古屋市における強雨事例（1999～2009年)

\begin{tabular}{|c|c|c|}
\hline 最大60分雨量生起日時 & 最大60分雨量 & 生起地点 \\
\hline \hline $2008.8 .290: 20$ & $113 \mathrm{~mm}$ & 北士木事務所 \\
\hline $2004.9 .516: 30$ & $107 \mathrm{~mm}$ & 瑞穂士木事務所 \\
\hline $2000.9 .1121: 10$ & $105.5 \mathrm{~mm}$ & 緑士木事務所 \\
\hline $2009.10 .86: 00$ & $98.5 \mathrm{~mm}$ & 鳴海 \\
\hline $1999.9 .1422: 40$ & $80 \mathrm{~mm}$ & 瑞穂土木事務所 \\
\hline $2001.8 .712: 10$ & $77.5 \mathrm{~mm}$ & 南陽 \\
\hline $2004.8 .720: 20$ & $73.5 \mathrm{~mm}$ & 名東土木事務所 \\
\hline $2001.8 .2613: 20$ & $73 \mathrm{~mm}$ & 北土木事務所 \\
\hline $1999.8 .2122: 30$ & $72.5 \mathrm{~mm}$ & 宝神 \\
\hline $2006.8 .1216: 20$ & $72 \mathrm{~mm}$ & 東谷山 \\
\hline
\end{tabular}

に向かっで沖縄近海の台風14号に伴う暖湿気流が南方か ら連続的に流入していた (図-1)。台風の動きが遅かっ たためにこの気圧配置は長時間持続し、四国から関東に かけての太平洋側各地に大雨をもたらした。中でも東海 地方の一部地域では $50 〜 100 \mathrm{~mm} / \mathrm{hr}$ 前後の強雨か数時間 にわたって続き、乥れが都市域と重なったために大きな 被害に結びついた。

著者らは、2000年9月11〜 12日の東海豪雨について、 愛知県、名古屋市、国土交通省、気象庁、JR東海、市町 村消防署等から計170地点の10分間雨量データを収集し た。雨域の分布を詳細に把握するため、愛知県西部を中 心に可能な限り多くの地点のデータを得るよう努めた。 また、三重県方面についても三重県、国土交通省、気象 庁所管の観測局計 82 地点の時間雨量データを収集した。

これら合計252地点の雨量データを基に作成した 9 月 11 〜12日の総雨量及び最大時間雨量の等雨量線図を図- 2 に示す。図 2 aより、総雨量のピークは、三重県南部、 愛知県西部、岐阜県南東部の3箇所にあることが分かる。 本研究で収集したデータの中て総雨量が最大となつた観 測局は大府駅 (愛知県大府市、JR東海所管) で、 $688 \mathrm{~mm}$ であった。

この総雨量の分布を図 $2 \mathrm{~b}$ の最大時間雨量の分布と比 較してみると、総雨量のピークか3箇所にあるのに対し て、最大時間雨量では愛知県西部のピークのみか際立っ て大きく、この地域には短時間強雨か㳔に集中したこと が分かる。252地点中、最大時間雨量が最大となった観 測局は東海 (愛知県東海市、気象庁アメダス) で、 114mm (11日18〜19時) であつた。なお、10分間雨量 データが得られる170地点について最大 60 分間雨量を求 めたところ、最大となった観測局は刈谷駅 (愛知県刈谷 市、JR東海所管) で、116mm (11日21:10〜22:10) で あった。最大 60 分間雨量 $100 \mathrm{~mm}$ 以上を記録した観測局は 計8地点あり、これらは全て名古屋市南東部から知多半 島基部にかけての地域に分布していた。

三重県中南部では9月10日深夜から雨か降り始め、11

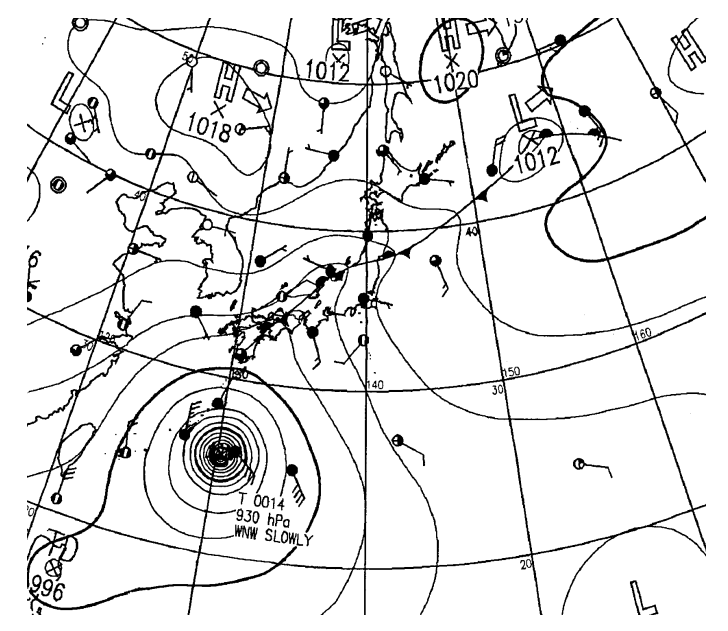

图-1 地上天気図 (2000年9月11日21: 00 , 気象庁提供) 

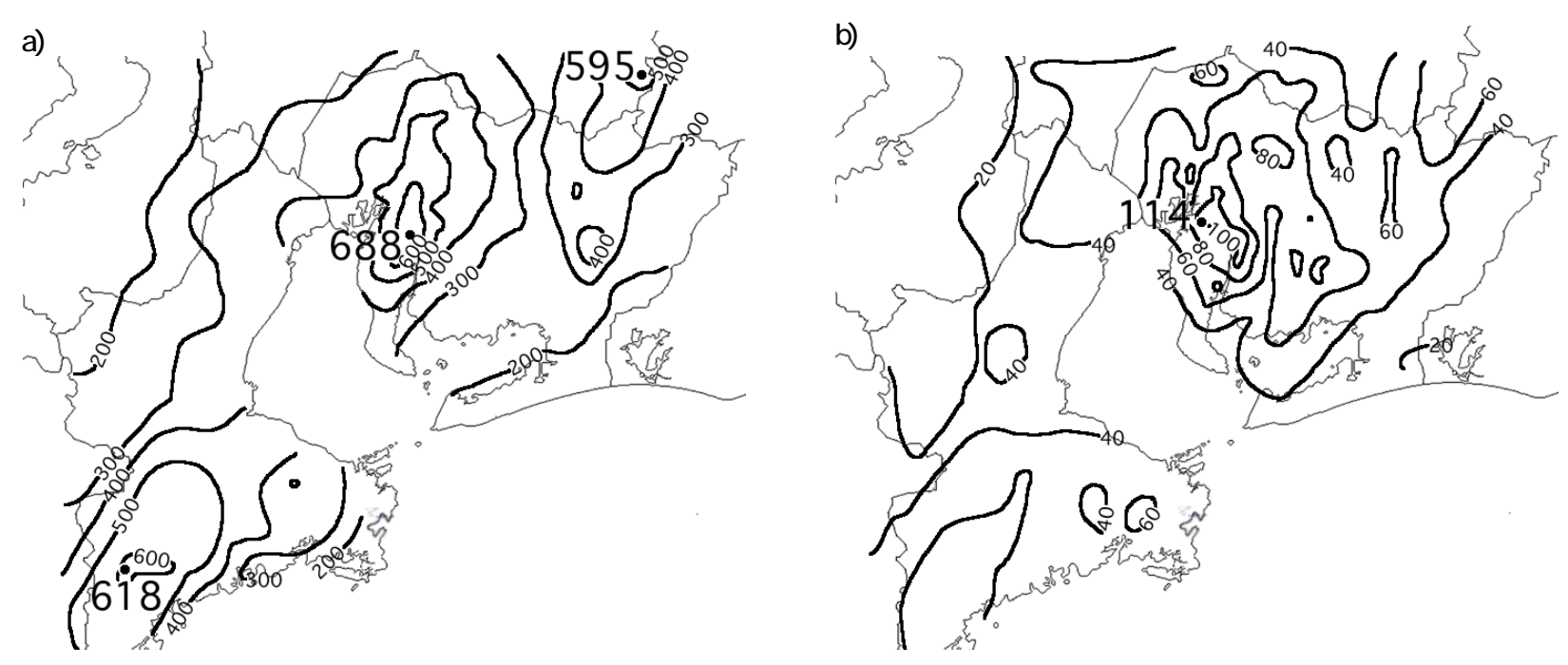

.図 2 2000年9月11〜12日の (a) 総降雨量と (b) 最大時間雨量
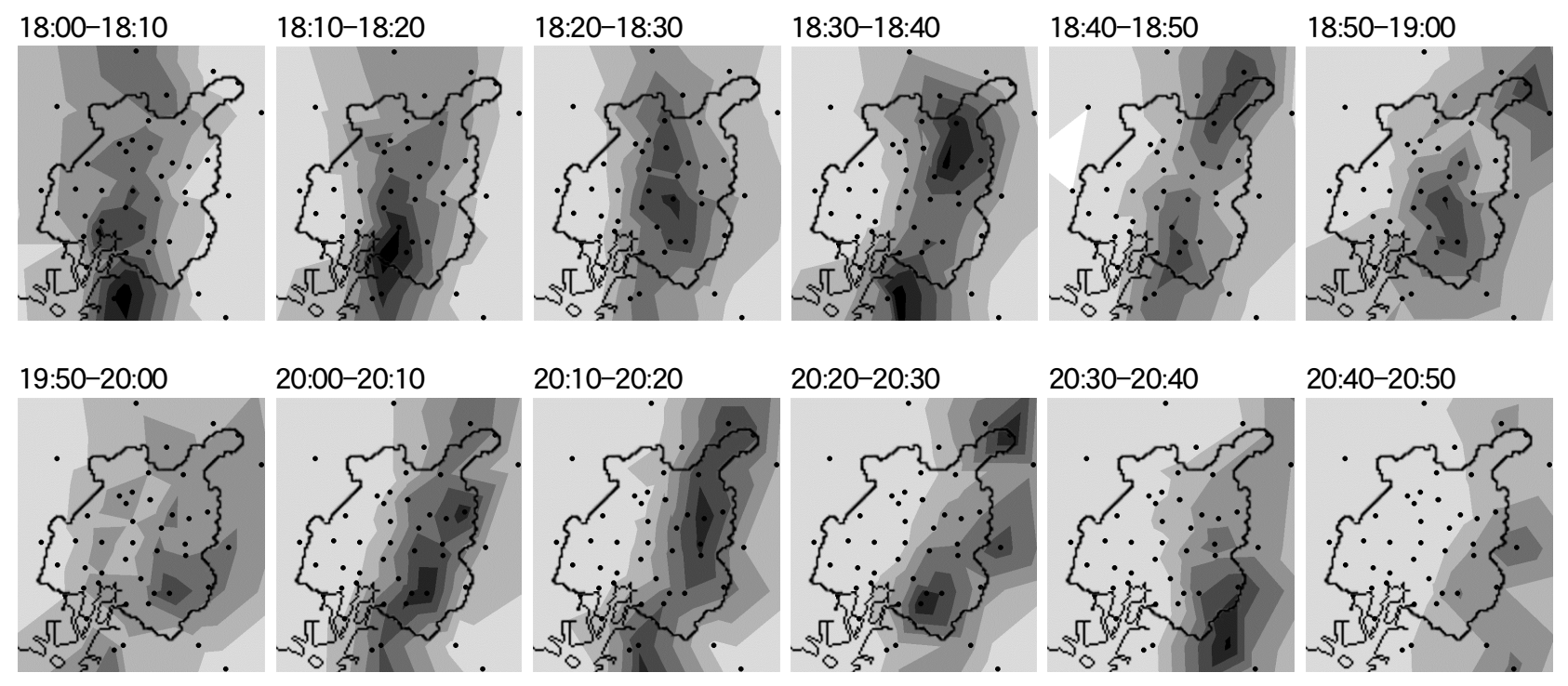

$0 \quad 20 \mathrm{~km} \quad 0 \quad 4 \quad 812162024(\mathrm{~mm} / 10 \mathrm{~min}$.

図-3 名古屋市域における10分毎の降雨量分布（2000年9月11日18:00～19:00，19: 50～20: 50），・は雨量計の位置を表す

日午前にはやや小降りになったが、午後から再び強まる とともに三重県中部から北に伸びる細長い降雨帯が形成 された。降雨帯は夕方から徐々に東へと移動し、愛知県

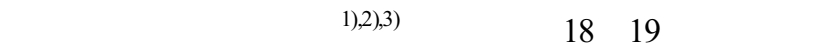
屋地方気象台て時間雨量 $93 \mathrm{~mm}$ 、東海のアメダス観測点 て時間雨量 $114 \mathrm{~mm}$ 観測された。深夜から降雨域はさら に東へ移動し、12日未明から早朝にかけては愛知・㞳 阜・長野県境付近の山間部力強雨の中心となった。

以下では、10分雨量データを用い、個々の強雨域につ いての発生・移動特性やメソスケールの気象状況との関 係について検討する。

b) 強雨域の移動特性

図３ は、名古屋市域において降雨がピークとなった、 11日18:00〜19:00及び19:50〜20:50についての10分毎の雨 量分布を示したものである。数〜10数 $\mathrm{km}$ 程度の大きさ
の強雨域が、南南西から北北東方向へと次々と移動して いる樣子を見ることができる。图-4 には、光の移動経 路に沿った5地点における10分間雨量の時系列グラフを 示した。グラフより、11日18～21時頃の強雨域の移動速 度は、ばらつきがあるものの平均的に見て $35 \mathrm{~km} / \mathrm{hr}$ (19 ノット）程度と読み取れる。11日21時の高層気象観測 データで500hPaの風向・風速を調べると、名古屋から最

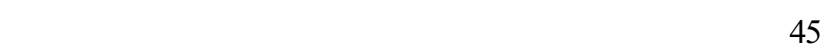
ノット、南南西25ノットであった。降雨セルの移動方向 は500hPa高度の風向に概ね対応し、移動速度は同風速よ りやや小さいことが分かる。

c) 雨域とメソ収束線との対応

次に、雨域の分布とメソスケールの気象状況との関係 を見るため、アメダス及び削方署等の観測データを基に、 11 日21時について地上風及び気温 $\left(5^{\circ} \mathrm{C} / \mathrm{km}\right.$ で每面高度に 

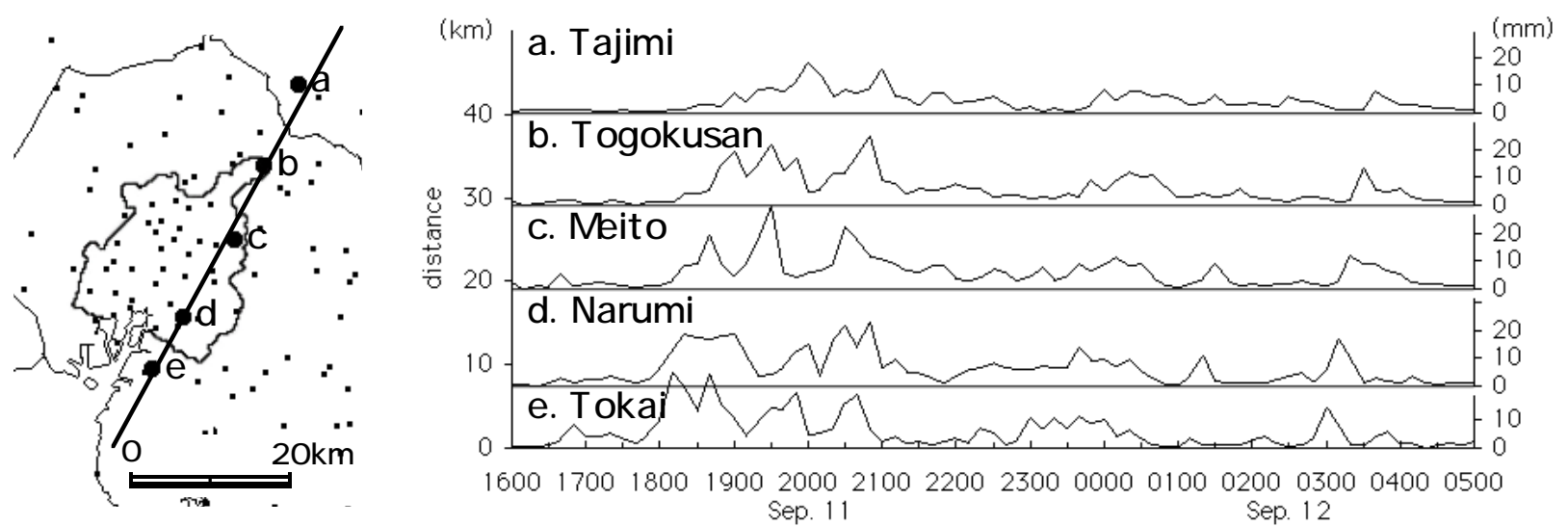

図-4 名古屋周辺の5地点における10分雨量値の時系列変化 (2000年9月11日16: 00 12日5: 00) ，・は雨量計の位置を表す

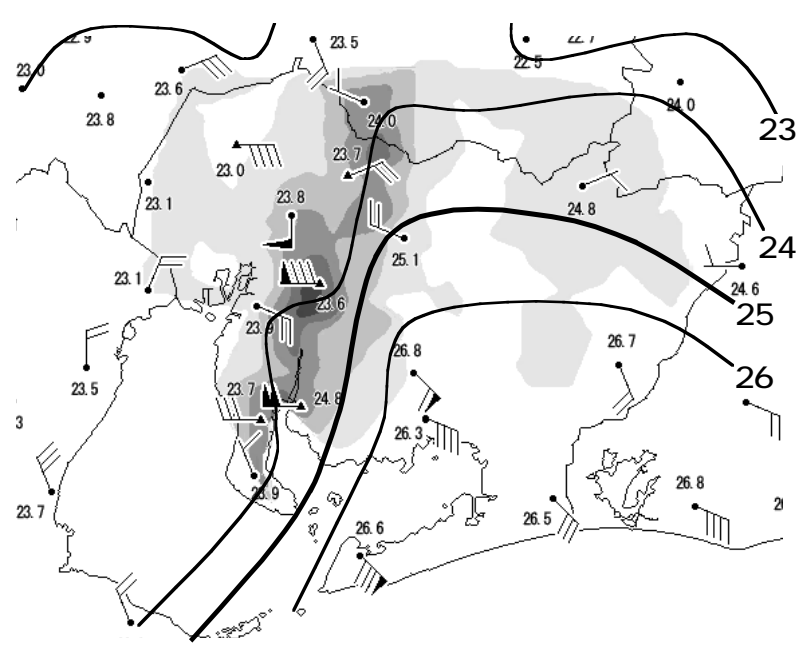

図 5 気温 (高度補正したもの) - 風速分布と10分雨量分 布との対応 (2000年9月11日21: 00)

補正) の分布図を作成し、前10分間雨量分布図と重ねて 図-5 に示した。知多半島基部などの強雨域の近傍では、 雨域から外に向かう冷気外出流力明瞭に認妨られる。風 向・気温の分布から、図上太実線で示した $25^{\circ} \mathrm{C}$ 等温線 にほほ対応した位置に収束線の存在力推定され、強雨域 はこの収束線の10〜 $20 \mathrm{~km}$ 程度寒域側に発生している。 このことは、これらの強雨か下層の南東からの暖湿気流 と内陸の冷気塊との衝突によって生成・強化された積乱 雲に伴うものであることを示唆している。地上雨量デー タからは確認できないが、この帯状降雨域は伊勢湾海上 を経て志摩半島付近まで伸びていることがレーダー画像 からは確認され3),4)、典型的なバックビルディンク型の豪 雨),6)であつたことが分かる。

収束線の暖域側の地上風は、11日夕方には東南東〜南 東風であるが、12日未明までに南南東〜南風に変化して いる。弚れに伴い、収束線は伊勢湾の湾口付近を軸に回 転するように徐々に南東へと移動し、強雨の中心は愛 知・岐阜・長野県境付近の山間部に移った。また、11日 22時30分頃を境に明瞭な帯状の降雨域は見られなくな る゙)。こうした収束線と雨域の挙動については、1983年9 月28日の豪雨にも類似した事例が見出される7)。
(2) 平成20年8月末豪雨

2000 年東海豪雨以降、東海地域では時間雨量 $100 \mathrm{~mm}$ 前 後に達する強雨力数回発生している。光の中でも代表的 なものが、2008年8月28日から29日にかけての深夜、名 古屋市域では1999年以降で最大の60分間雨量 $113 \mathrm{~mm}$ 観 測され (表-1 参照) 、岡崎市を中心に甚大な浸水被害 をもたらした平成 20 年 8 月末豪雨である。この時、日本 付近には東海豪雨時とほぼ同じ位置に前線が停滞してお り、西南方の低気圧とはるか東の海上に位置する高気圧 により、東海地域には南東から暖湿な気流が流入しやす い条件にあった。

愛知県、名古屋市及び気象庁アメダスの観測局計 114 地点の 10 分雨量データから求めた愛知県及び近接地域に おける総降雨量 (8月28〜29日) と最大 60 分間雨量の分 布を図 6 に示す。総降雨量のピークは304.5mm (岡崎、 気象庁アメダス) と東海豪雨と比較すると小さいが、 1 時間程度の時間スケールでは東海豪雨に匹敵ない儿上回 る強雨か発生していたことが分かる。60分間雨量のピー クは岡崎 (気象庁アメダス) の146.5mm（29日1:00〜 2:00) 、次いで一宮 (気象庁アメダス) の120mm (28日 22:10 23:10) 、北土木事務所 (名古屋市) の113mm

(28日23:20〜29日0:20) であつた。県西北部の一宮から 東南方の名古屋、岡崎へと約 3 時間かけて降雨域力䔟動 したことか㴦える。なお、2000年東海豪雨時には、一宮、

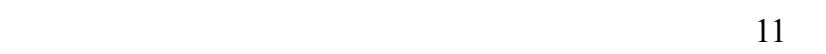
17:00〜18:00、18:10〜19:10、12日0:20〜1:20頃であり、 降雨域の移動に7時間以上を要している。この移動速度 の小ささか非常に大きい総降雨量に寄与したといえる。

図-7 は、名古屋における降雨ピークにあたる28日 23:20〜29日0:20についての10分毎の雨量分布図である。 東海豪雨時と同樣に直径数〜10数 $\mathrm{km}$ 程度の降雨セルが 北 (あるいは北北東) の方向に次々と移動している樣子 が見られるが、移動速度は東海豪雨時よりやや小さい。 10分雨量分布図から降雨セルの大まかな移動速度を求め たところ、 $25 \mathrm{~km} / \mathrm{hr}$ (13ノット) 程度であった。名古屋 地方気象台におけるウィンドプロファイラデータ (図8) から、この場合にも降雨セルの移動方向は上空4〜 
$5 \mathrm{~km}$ 付近の中層風の風向に概ね対応していることが分か る。また、地上付近の風向は28日23時頃に南東から北西 へと反転しており、降雨ピークの少し前に収束線が名古 屋を通過したことが分かる。

\section{3 . 愛知県における短時間強雨の発生特性}

以上、名古屋市周辺で近年発生した $2 つ の$ 代表的な豪 雨事例について、メソスケールの収束線と密接に関係し た帯状の降雨域によってもたらされたことを確認した。

a) 総降雨量

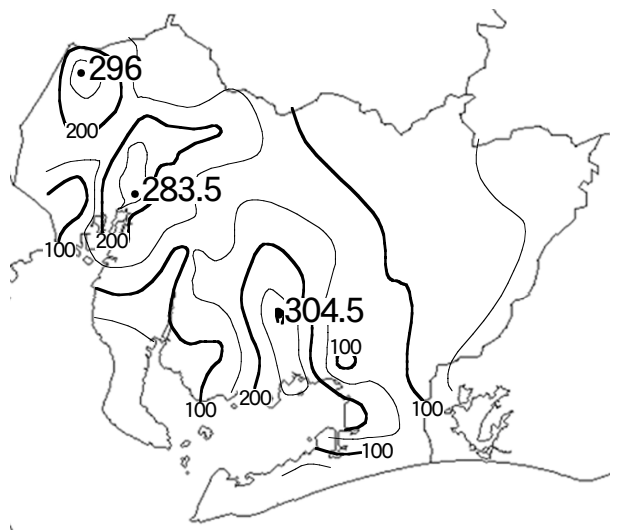

b) 最大 60 分雨量

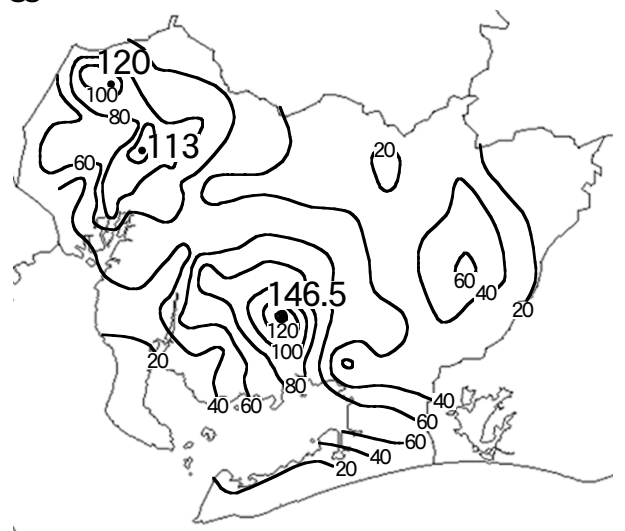

図- 6 2008年8月28〜29日の (a) 総降雨量と (b) 最大 60 分 間雨量
愛知県西部に現れたメソ収束線に伴う帯状降雨域によ る大雨の事例については過去にも幾つかの報告がある。 例えば、1972年7月12〜13日の西三河豪雨では、2000年 東海豪雨と同樣に知多半島基部付近て帯状降雨域力停滞 しており、強雨力観測された範囲も東海豪雨と概ね一致 する ${ }^{8)}$ 。両者には気象状況等でも幾つかの共通点か涽摘 されている゙)。

伊勢湾周辺の地域力湳東よりの下層風が流入しやすく、 かつ接地冷却による冷気塊が内陸側に形成されやすい条

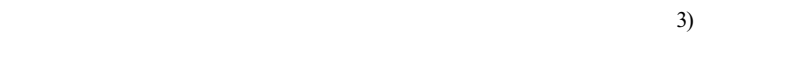
知多半島から西三河地方にかけての丘陵地形がこの地域 における雨域の発生・停滞に何らかの役割を果たしてい る可能性も考えられる。弚うしたことから、知多半島を 中心とする地域では、類似の気象条件による短時間強雨 が他にも時折発生している可能性が考えられる。

図-9 は、1987〜2008年の22年間について10分間雨量 データが得られる愛知県所管の 45 観測局において、この 期間に 180 分間雨量が $100 \mathrm{~mm}$ 以上を記録した総日数を地 点毎に求め、光の分布を地図上に表したものである。強 雨頻度が最大となったのは作手 (旧南設楽郡作手村) の 13であるが、周囲と比較して1箇所だけ極端に大きい值 のため、雨量計周囲の局所的な環境等か関係している可

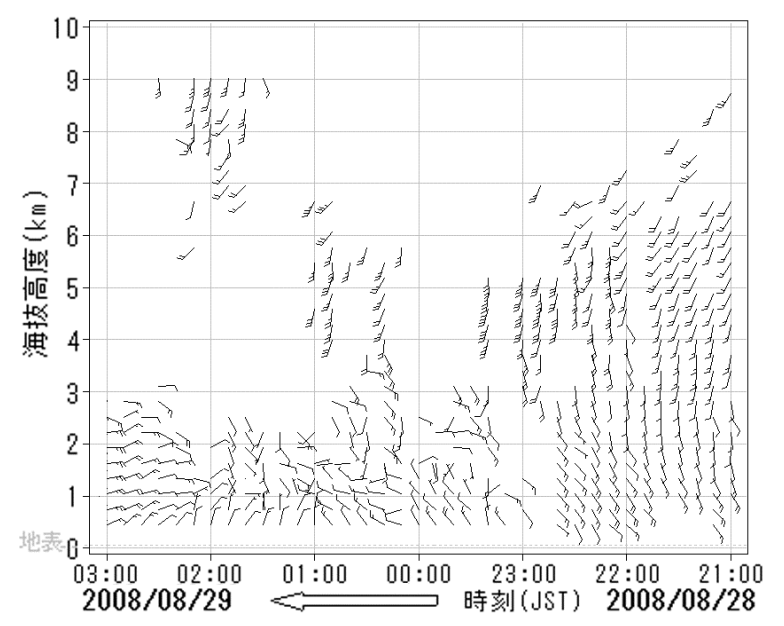

図-8 名古屋におけるウィンドプロファイラデータ (2008 年8月28日21:00〜29日3: 00 , 気象庁提供)

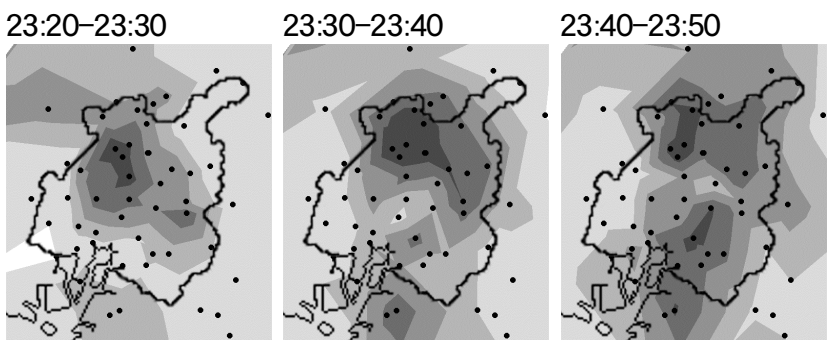

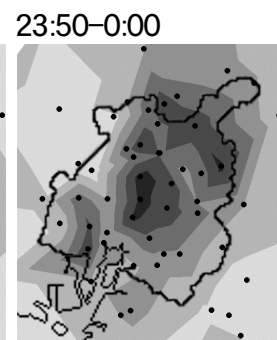

0:00-0:10

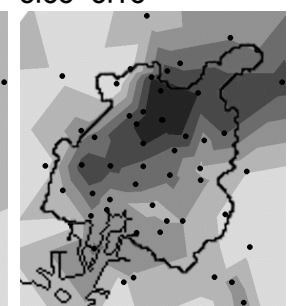

0:10-0:20

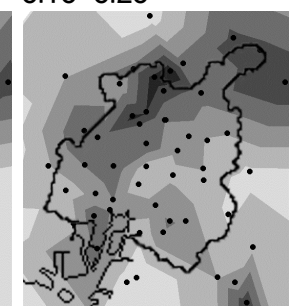

$20 \mathrm{~km} \quad 0 \quad 4 \quad 812162024$ (mm/10min.)

図-7 名古屋市域における10分毎の降雨量分布（2008年8月28日23: 20〜29日0: 20），・は雨量計の位置を表す 


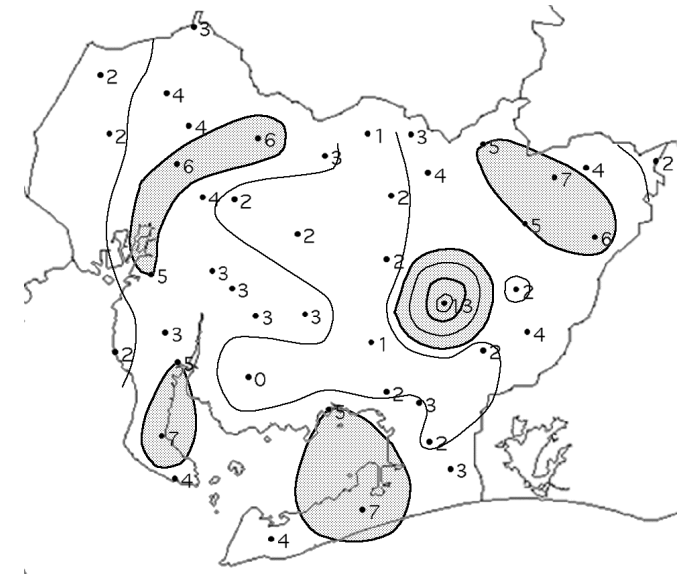

图- 9 愛知県における180分間雨量100 mm以上の発生日数の 分布（1987〜2008年），網掛け部は5日以上の領域

能性も考えられる。乥れ以外では、奥三河山間部、渥美 半島東部、知多半島東部及び名古屋市付近に極大域力認 められた。なお、180分間以外にも10分単位から数時間 程度まで樣々な継続時間について同樣の解析を行つたが、 奥三河や渥美半島の強雨頻度の極大域は何れの継続時間 でも認められたのに対し、知多半島〜名古屋の極大域は 継続時間180分前後の場合のみ明瞭に認められた。

知多半島基部を中心とする一帯の平野部は、何れの季 節についても総降水量が県内で最も少ない地域に分類さ れている゙”。ここて継続時間か3時間程度の強雨のみ発生 頻度か極大となったことは、この地域力時折発生する特 定の気象状況に対してのみ強雨を生じやすい地形条件に あることを推測させる。本稿で述べたようなメソ収束線 の停滞がこれに関係している可能性もあり、今後は個別 の事例について、どのような気象条件でこの地域に強雨 域か漋じたのかを検討していく必要があろう。

\section{4 .おわりに}

本稿では、主にメソスケールの現象に焦点を絞り、地 上雨量データを用いて 2000 年東海豪雨と平成 20 年 8 月末 豪雨の雨域特性を解析した。10分間雨量データの解析に より、強雨発生時に愛知県西部では大きさ数〜10数 $\mathrm{km}$ 程度の強雨域が20 40km/hr程度の速さで南南西から北 北東の方角へ次々と通過し、全体として帯状の降雨域を 形成している樣子が再現された。乥れら強雨域の移動方 向は500〜700hPa付近の中層風の風向に概ね一致し、光 の出現位置はメソスケールの収束線の寒域側 $10 〜 20 \mathrm{~km}$ 付近にあった。帯状の降雨域は時間経過とともに愛知県 西部から徐々に南東へと移動したが、東海豪雨で光の 途上に知多半島付近て停滞し、知多半島基部から北北東 に伸びる帯状の領域に特に集中した大雨をもたらした。 また愛知県の過去 22 年間の 10 分間雨量データの解析から、 知多半島北部から名古屋付近にかけての地域て継続時間
3時間程度の強雨の発生頻度が高いことが分かつた。

本稿て扱った2つの豪雨事例が共通してメソ収束線に 関連したバックビルディンク型の降雨であることは以前 から指摘されており10111)、光のメカニズムについても解 明が進んでいるが、こうたメソスケールの現象におい て強雨域の出現位置や時刻、移動速度等を予測するのは 依然容易ではない。今後さらに多くの強雨事例について 本稿と同樣の手法で帯状降雨域や個々の降雨セルの出現 位置、移動速度等と気象状況との関連を解析し、過去の 観測データに基づく経験的・統計的アプローチと物理モ デルによるアプローチの両面から局地的強雨の予測手法 の開発につなげていきたいと考えている。

謝辞 : 観測データをこ提供いただいた愛知県、名古屋市、 国土交通省、気象庁、東海旅客鉄道( 株)、三重県、㴥方 署等の関係各機関に謝意を表したい。また、気象解析に 有益な示唆をいただいた日本気象予報士会東海支部の諸 氏にも謝意を表す。なお本研究は、(財) 河川環境管理財 団の河川整備基金助成事業によって実施した。

\section{参考文献}

1）渡辺真二, 窪田邦晃, 木下信好, 过川才太, 森岩聰, 中條 屋博 : 平成12年9月11日 12日の記録的な大雨, 第17回日本 気象学会中部支部研究会概要集, pp.55-60, 2000.

2) 水文・水資源学会東海豪雨災害調査委員会 : 2000年9月東海 豪雨災害の実態と教訓, 水文・水資源学会誌, Vol.14, pp.411-432, 2001.

3) 渡辺真二 : 東海豪雨の観測と解析，2001年度日本気象学会 秋季大会シンポジウム「東海豪雨 - 自然・都市・人間の関 わり 一」, 日本気象学会中部支部, pp.1-14,2001.

4) 金田幸恵, 若月泰孝, 坪木和久, 武田喬男: 東海豪雨のメ カニズム 一光の雨をもたらしたものー，2001年度日本気象 学会秋季大会シンポジウム「東海豪雨 - 自然・都市・人間 の関わり-」, 日本気象学会中部支部, pp.15-24,2001.

5）小倉義光 : メソ気象の基礎理論, 東京大学出版会, pp.172176, 1997.

6) 吉崎正憲, 加藤輝之 : 豪雨・豪雪の気象学, 応用気象学シ リーズ 4 , 朝倉書店 , pp.92-115, 2007.

7) 服部満夫 : アメダス・レーダー・GMS赤外画像を用いた台 風第8310号による東海地方の豪雨の解析, 気象府研究時報, Vol.39, pp.91-108, 1987.

8) 瀬下慶長, 田中隆一 : 昭和47年7月12日 13日の西三河集中 豪雨の降水解析，天気，Vol.22,pp.131-137, 1975.

9）長尾正志 : 計画降雨策定からみた東海地方における集中豪 雨域の特性解析, 自然災害資料解析, Vol.6, pp.48-61, 1979.

10) 肆矢朗久, 坪井嘉宏 : 2008年8月28～29日に愛知県で発生し た大雨について, 平成 20 年度気象学会中部支部研究会講演 要旨集, pp.57-62, 2008.

11) 條田太郎 : 集中豪雨をもたらす降水システムの構造 〜平成 20 年 8 月末豪雨を例として, 第16回日本気象学会中部支部公 開気象講座「集中豪雨」, pp.8-13,2010.

(2010. 9. 30受付) 